\title{
Green façades and in situ measurements of outdoor building thermal behaviour
}

\author{
Marina Paschoalino de Jesus, M.D *, Júlia M. Lourenço, Rosa M. Arce, Manuel Macias, PhD \\ Departamento de Engenharia Civil, Universidade do Minho, Campus de Azurém, 4800-058 Guimarães, Portugal
}

\section{A R T I C L E I N F O}

\section{Article history:}

Received 28 December 2016

Received in revised form

28 March 2017

Accepted 29 March 2017

Available online 31 March 2017

\section{Keywords:}

Green façades

Urban thermal behaviour

Urban sustainability

Microclimate in urban areas

Urban heat island

\begin{abstract}
A B S T R A C T
Using green façades in large cities with hot climates has been introduced in the search for more sustainable solutions for urban development. This paper presents the data collected in situ and quantifies the thermal external behaviour of a green wall and a bare one in the same surrounding environment in the city centre of Madrid, Spain. The methodological approach helps to assess the impacts of both walls on the variation of the urban temperature range at the microclimate scale in accordance with environmental physical data at different seasons and times of the day. In the summer campaign, the maximum values of air temperature reduction as measured in situ range between $2.5^{\circ} \mathrm{C}$ and $2.9^{\circ} \mathrm{C}$ which confirmed the values of various other studies using similar measurements. In the autumn campaign, the maximum values were half of the ones obtained for the summer, not exceeding $1.5^{\circ} \mathrm{C}$. However, these values increased after calculating similar conditions of sunlight in both façades. This comparative analysis of the experimental results on a green wall and a bare wall demonstrates that green façades can have a significant temperature reduction potential in the surrounding microclimate.
\end{abstract}

(c) 2017 Elsevier Ltd. All rights reserved.

\section{Contents}

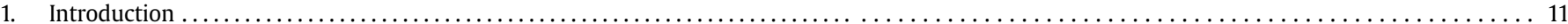

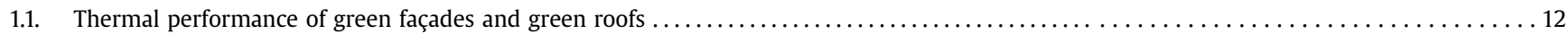

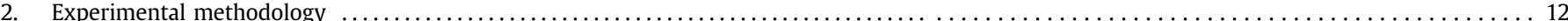

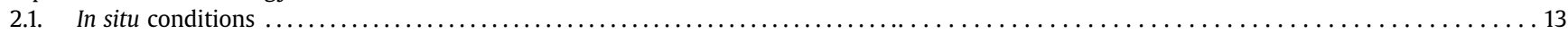

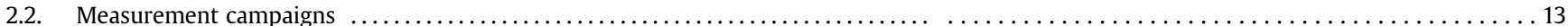

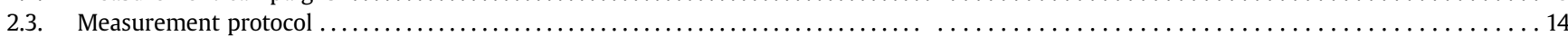

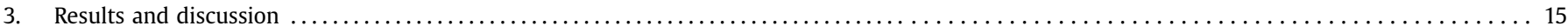

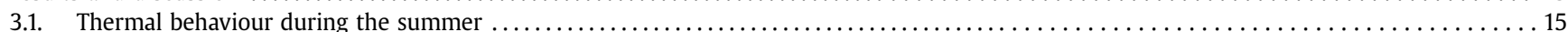

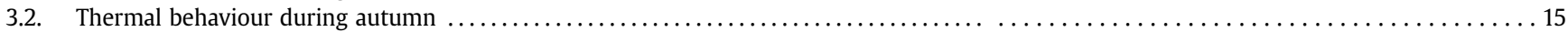

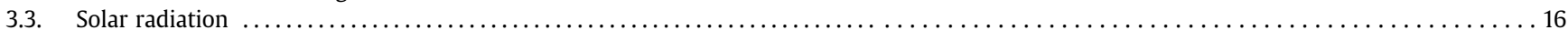

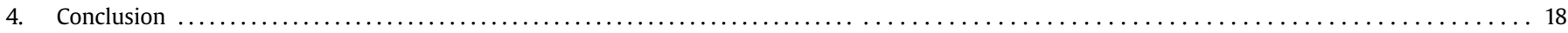

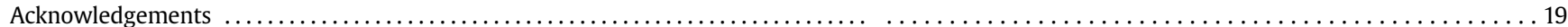

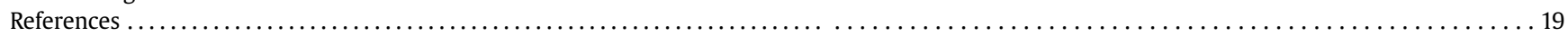

\section{Introduction}

The type of land use cover plays an important role in

\footnotetext{
* Corresponding author.

E-mail address: marinadejesus@gmail.com (M.P. de Jesus).
}

determining the urban climate [1]. Due to the expansion of urban areas, especially after the Industrial Revolution, the type of occupation in urban areas underwent significant changes. Previous to this expansion, there were areas predominantly covered by natural vegetation, whereas nowadays most of them are covered by asphalt and concrete. The changes occurring in the properties of the soil surface that has, to a large extent, become impervious and the 
absence of natural vegetation in urban areas have resulted in local changes in the climatic conditions of urban environments, such as urban "heat islands". Heat islands occur especially in the central areas of large urban centres where there is a significant increase in air temperature compared to the surrounding areas. Their consequences are the increase in pollutants in the atmosphere and higher costs to meet increased energy demands for cooling needs, which consequently leads to an increase in environmental impacts due to resource extraction. In Spain, according to a report by Madrid City Hall, it was found that green roofs, vertical gardens and groves reduce the energy consumption of buildings by $14 \%$ in the summer and a temperature reduction of $4{ }^{\circ} \mathrm{C}$ was documented in green areas [2].

Nevertheless, environmental problems associated with "heat islands" are influenced by other parameters and physicalenvironmental variables, as well as the type of land use.

For example, solar radiation that provides heat to the human metabolism of thermoregulation, the exposure of the human body to wind by exchanging heat through convection and climatic variables, such as temperature and humidity, also affect the thermal comfort [3].

The case study herein presented focuses on assessing the reduction potential of the thermal conditions of the urban environment in the presence of green façades. The aim is to compare the thermal behaviour of a façade covered with vegetation and a bare façade inserted in the same microclimate in the centre of Madrid, Spain. Air temperature variables, solar radiation, relative humidity and wind speed were collected in situ. Results of climatic variables were compared, relating the thermal behaviour of both façades in different seasons and day times.

\subsection{Thermal performance of green façades and green roofs}

Various studies on green façades and green roofs using in situ measurements or simulation models have analysed their thermal performance. Experimental investigation was conducted in Spain in order to clarify the various mechanisms that influence the use of green façades and their behaviour as passive systems for energy saving purposes. Four fundamental mechanisms were considered by the researchers: solar radiation interception; thermal insulation provided by vegetation; evaporative cooling; and wind variation on buildings. The results obtained from the spring and summer campaigns confirmed that green façades have a large capacity to intercept solar radiation. The radiation, temperature and humidity measurements confirmed the creation of a microclimate in the intermediate space, characterized by a lower temperature and higher humidity $[4,5]$. In the Netherlands, relevant effects were also quantified using green façades with measurements taken in the interspace between the frame and the façade, where the vertical greening systems have shown to be effective natural sunscreens due to a reduction in surface temperature of the green layer compared to a bare façade. Green façades are effective wind barriers because they reduce the wind speed in the building envelope, thus improving the energy efficiency [6,7]. Various studies were conducted in Germany [8] to identify and assess the cooling benefits of green façades. A study was carried out on a wall covered with plants and a bare wall with no vegetation. The results show a temperature reduction in the green façade in the range of $2{ }^{\circ} \mathrm{C}-6{ }^{\circ} \mathrm{C}$ compared to the bare wall.

Various comparative studies on a façade covered by greenery and a bare façade were explored in situ. To assess the magnitude of the cooling from vegetation in urban areas, a study was conducted in the city of Nagoya, Japan, where air temperatures during the summer are close to $40{ }^{\circ} \mathrm{C}$. It was observed that the impact of shadowing and evapotranspiration of plants can significantly reduce the amount of heat that will be retransmitted by façades and other surfaces. The shading and cooling potential of a green coverage parking lot showed a temperature reduction from $2{ }^{\circ} \mathrm{C}$ to $4{ }^{\circ} \mathrm{C}$ [9]. In the Mediterranean climate of Greece, a comparison was made between façades with and without vegetation focusing on variations in temperature and dynamic thermal characteristics of wall surfaces for both cases. The contribution of the indoor green wall is important to improve the thermal behaviour of its surroundings $[10,11]$.

In Taiwan, a comparative experiment was carried out between a planted lawn and a sun exposed slab. The results confirmed that the rooftop lawn contributes to benefits in the surrounding outdoor environment and a decrease in the internal energy demand [12]. Another comparison [13] made between a black painted roof and a green roof covered by vegetation showed a $50 \%$ reduction in the sensitive flow of the green roof in the Mediterranean climate with dry warm summers in Portland, Oregon. It was observed that the albedo of the material may decrease temperature surfaces exposed to solar radiation [14].

The effects of vegetation and high albedo of the materials were investigated in the Mediterranean climate of Rome. It was found that the vegetation significantly benefits the environment and high albedo materials can alleviate the thermal load of buildings especially higher thermal stress in the summer months [15]. In Singapore, eight different green façade systems were measured at different distances. Results confirm a reduction of temperature in the surrounding environment of up to $3.33^{\circ} \mathrm{C}$ at $0.15 \mathrm{~m}$ from the wall [16].

A series of numerical simulations were also conducted in order to evaluate the performance of green façades. The importance of using green façades is highlighted to reduce heat island effects in hot, dry weather microclimates whereby substantial benefits in reducing urban temperatures can be achieved. For example, a reduction of $8.4^{\circ} \mathrm{C}$ was obtained in the simulation of an urban canyon [17] and materials with very different reflection properties were large scale modelled in Greece, where the increase in the albedo represented a $2{ }^{\circ} \mathrm{C}$ decrease in air temperature [18]. In the USA, green roofs and the seasonal behaviour of the heat flux were modelled for a humid continental climate. It was observed that the widespread adoption of green roofs and surfaces covered with vegetation can reduce the temperature in the urban environment in the range of $2{ }^{\circ} \mathrm{C}-3{ }^{\circ} \mathrm{C}$ due to the increase of the albedo and evapotranspiration $[19,20]$.

\section{Experimental methodology}

The first phase of the research included planning the experimental work. The site selection was more problematic than expected due to the difficulties in finding a green wall with good vegetation conditions. For example, unique structures such as Air Trees were completely depleted of vegetation as they dried out between the work planning in the office and the first site visit. Having found the Caixa Forum green wall in perfect conditions, problems arose to find a suitable comparative bare wall. These conditions are further described below. The next steps involved, among others, selecting some equipment, as well as establishing the protocol and campaign times for in situ measurements. The next phase involved experimental investigation and in situ data collection comprising 144 measurements of climatic air temperature parameters, humidity, air velocity and solar radiation. After each of the two in situ campaigns, the data was analysed and computed. A solar radiation conversion was performed for the bare wall as it had a different orientation from the green wall. Data obtained for the two walls were compared with and without solar conversion. The two campaigns of in situ measurements were 
carried out in different seasons of the year: in the summer, where higher average temperatures are observed, and in the autumn period, where average temperatures are lower. The in situ measurements of the climatic parameters were monitored over six days and throughout three periods of the day.

\subsection{In situ conditions}

The case study relies on data collected in situ from two measurement campaigns at different times in the Caixa Forum Museum, located near Retiro, an area in the city centre of Madrid. This microclimate can be found in the Mediterranean continental climate. Madrid has an annual daily average temperature between $2{ }^{\circ} \mathrm{C}$ and $14^{\circ} \mathrm{C}$. During the day, in the summer, average daily annual temperatures range from $24{ }^{\circ} \mathrm{C}$ to $30^{\circ} \mathrm{C}$ while in the winter, these temperatures range from $6{ }^{\circ} \mathrm{C}$ to $12{ }^{\circ} \mathrm{C}$. In this urban microclimate [21], there is a vertical garden located at Lat. $40^{\circ} 24^{\prime} 39.97^{\prime \prime} \mathrm{N} /$ Long. $3^{\circ} 41^{\prime} 35.41^{\prime \prime} \mathrm{W}$ that was designed by French landscape architect Patrick Blank. Its dimensions are $24 \mathrm{~m}$ high and $19 \mathrm{~m}$ long (Fig. 1) and it is called Wall 1 for purposes of this study analysis. Another wall, subject to the same environmental conditions, was successfully located in the proximity at Lat. $40^{\circ} 24^{\prime} 38.92^{\prime \prime} \mathrm{N} / 3^{\circ} 41^{\prime} 35.54^{\prime \prime} \mathrm{W}$ and was also selected for analysis. It is a bare wall and is called Wall 2. The location of the bare wall meets recommended standards between an ideal distance within a radius of $50 \mathrm{~m}$ and a maximum acceptable distance less than $100 \mathrm{~m}$ from the object of study $[22,23]$.

This guideline instruction is not easy to follow in urban areas with real existing buildings where a variety of problems can occur such as unparallel walls, walls blocked by vegetation, especially trees or green strips, short pavements and heavy traffic that do not allow for the same environmental conditions.

It is important to highlight the known complexity of in situ measurements which address problems related to in situ conditions. This has been investigated in various studies [24,25] where many in situ measurements were rejected due to damage caused to equipment left in the open air for $24 \mathrm{~h}$ without close supervision. Therefore, the best solution for field measurement campaigns, when there is no possibility of monitoring continuous data of physical-environmental variables by installing fixed equipment, is to adopt a simplified and reduced time campaign. This approach limits the isolation and quantification of all physical and environmental variables that influence thermal behaviour in the microclimate but it makes the in situ analysis feasible. Another problem that can be encountered in the field is the choice of the reference wall among the existing walls. Such was the case in this research. In fact, it is not easy to find parallel façades that are either accessible to measurements or similarly quantifiable in terms of general characteristics such as door and window openings. Other important constraints include incoherent conditions created in the streets by the comparative shortage of pavements or the existence of arboreal nuclei that do not allow access to the façade (Fig. 2).

The adopted methodology [23] successfully analysed the thermal behaviour of urban spaces in the presence of vegetation and its correlation with a reference point without having vegetation using data collection at a distance between 50 and $100 \mathrm{~m}$ from the urban environment under analysis [22]. These field conditions implied that the radius of incidence in the search for the reference façade was extended up to $100 \mathrm{~m}$. Digital map analysis and field visits were carried out to search for a reference façade that met all the listed requirements including the same solar orientation conditions, but it was not possible. It was observed that the two façades are not exposed to the sun in the same way as Facade 1 points to the Southeast and Facade 2 points to North-Northeast. Owing to such real limitations found in the field, this feasible solution was adopted as an opportunity to minimize the spatial problems. This solution meant that the solar radiation incidence measurements on the reference façade had to be numerically converted.

\subsection{Measurement campaigns}

To systematize in situ measurements of the climatic parameters

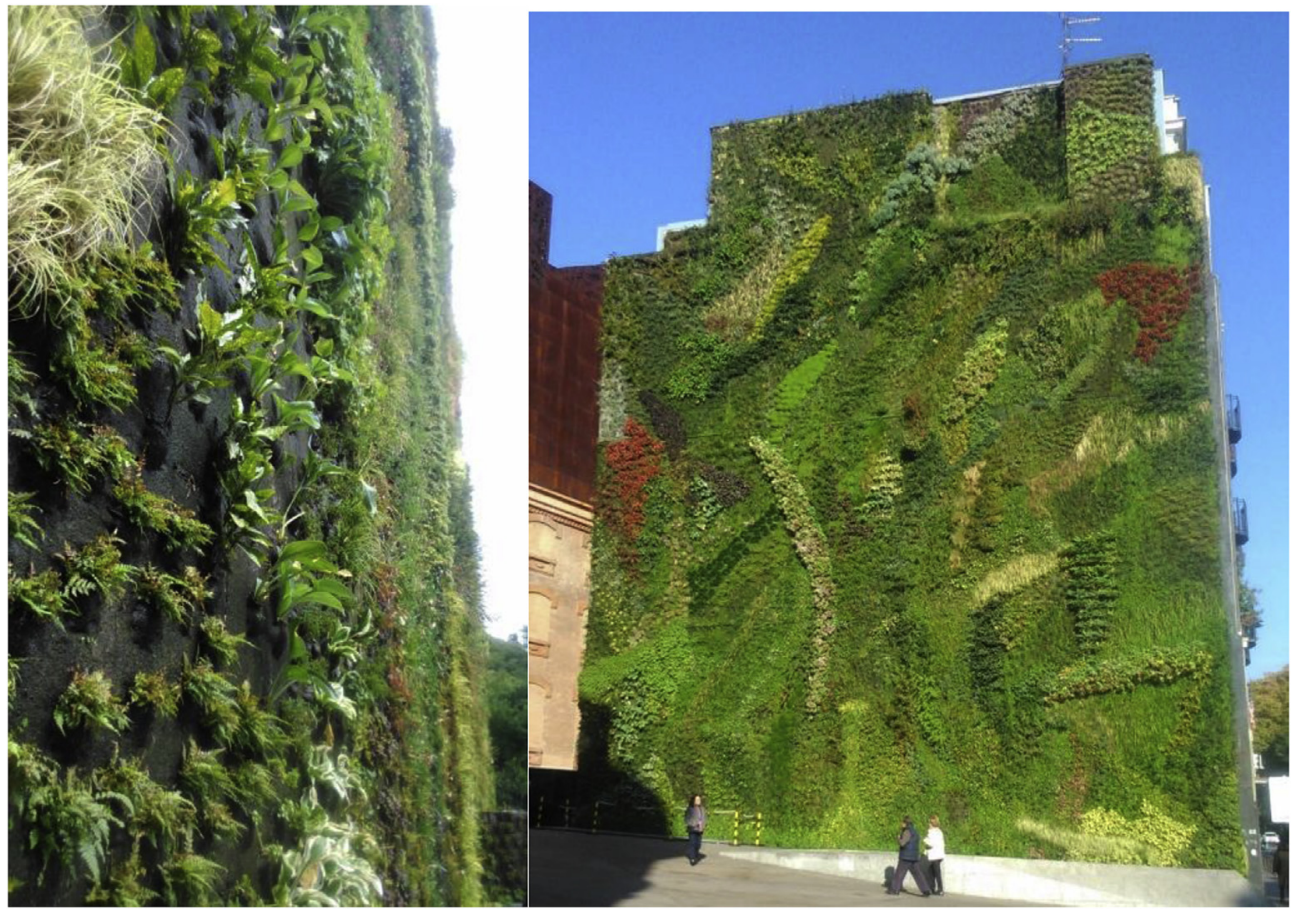

Fig. 1. Green wall installation (Wall 1) at the Caixa Fórum Museum, Madrid, Spain. 


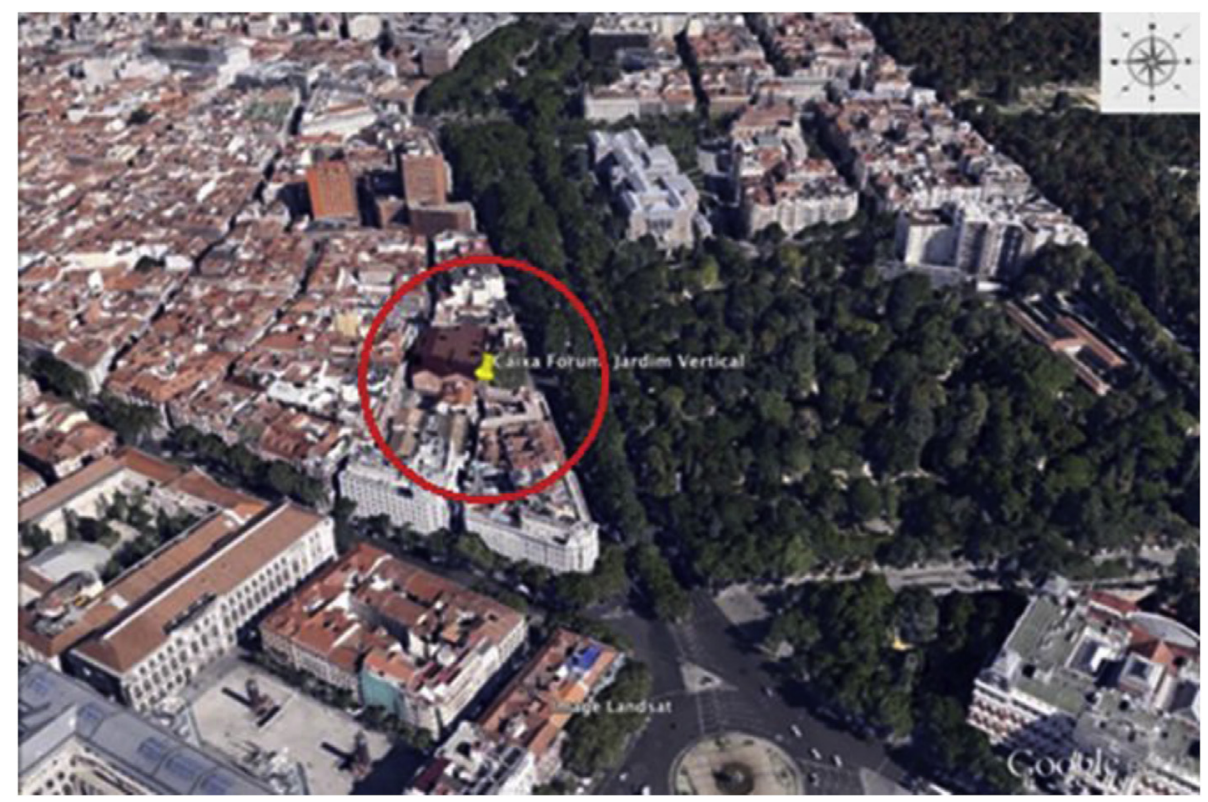

Fig. 2. Spatial location of the case study at the Caixa Fórum Museum, Madrid, Spain.

of temperature, humidity and wind speed, it was decided to perform measurements in three periods of the day so that different temperature ranges were collected. In the first measurement campaign, held on September 23, 24 and 25, 2015, the measurements were taken in the morning (between 10:00 a.m. $-11: 00$ a.m.), in the middle of the day (between 1:00 p.m. $-2: 00$ p.m.) and in the afternoon (between 3:00 p.m. - 6:00 p.m.). In the second measurement campaign, held on November 16, 17 and 19, 2015 due to the autumn period, measurements were taken on average $1 \mathrm{~h}$ in advance when comparing the respective measurements to the first campaign. Eight different points were selected for measuring, four for each of the walls (Wall 1 - Green Wall and Wall 2 - Bare Wall), and four at distances of $0.5 \mathrm{~m}$ (Point 1), $1.5 \mathrm{~m}$ (Point 2), $3 \mathrm{~m}$ (Point 3 ) and $5 \mathrm{~m}$ (Point 4) (Fig. 3).

\subsection{Measurement protocol}

The measurement approach was based on field work (Fig. 4) procedures mentioned in the literature, such as the studies that successfully analyse the thermal performance of urban spaces in the presence of vegetation and its correlation with a reference point, without vegetation [6,8,11,22]. Generally, field measurements were performed on average for 3 days and preferably on clear days, and spot measurements every 3-4 h [9,15,16,22-24].

The experimental research took into account the strategies adopted in previous studies $[4,11,22,23]$ which provided the first measurement campaign in order to analyse the urban thermal behaviour in the summer period, when higher average temperatures are observed. For the purpose of comparative analysis of different thermal behaviour, according to various other studies

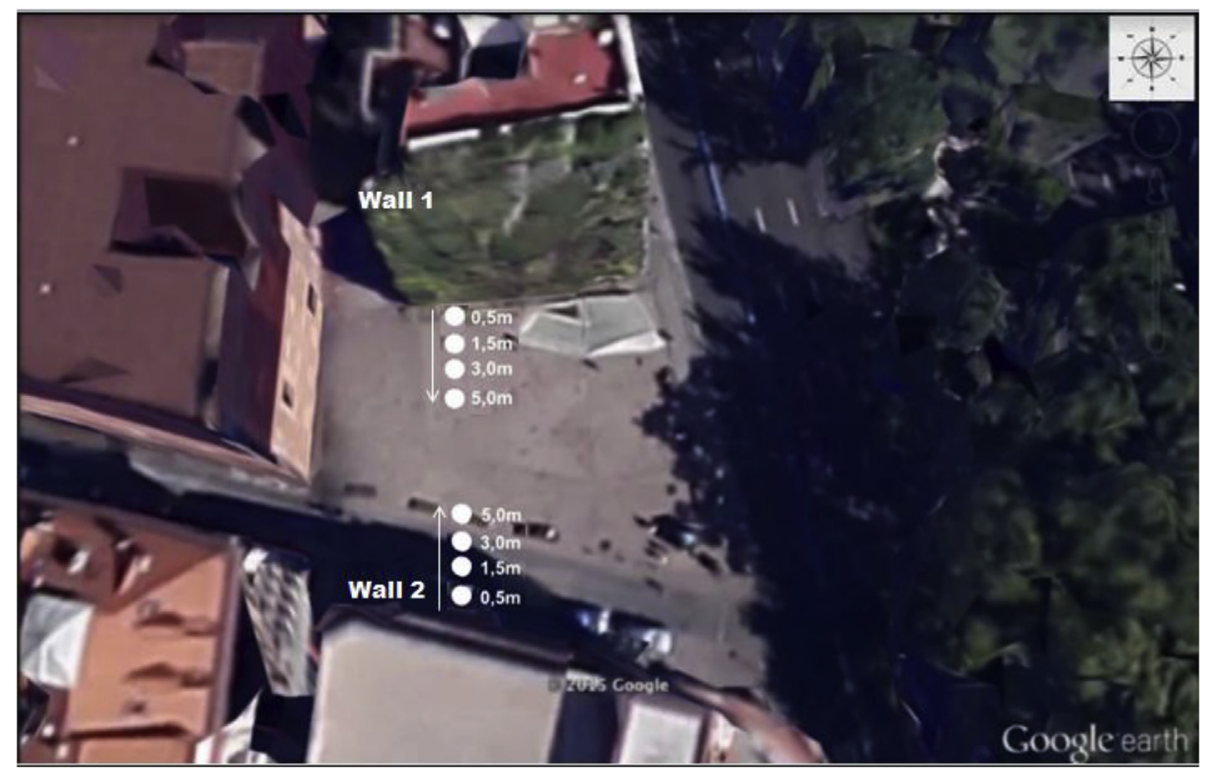

Fig. 3. Points for measurements and walls (Wall 1- Green Wall and Wall 2 - Bare Wall). 


\begin{tabular}{|c|c|c|c|c|c|c|c|c|}
\hline \multirow[b]{2}{*}{ Location } & \multirow[b]{2}{*}{ Climate } & \multicolumn{3}{|c|}{ Object of Study } & \multicolumn{2}{|c|}{ Period/Se ason } & \multirow[b]{2}{*}{ Campaign } & \multirow[b]{2}{*}{ References } \\
\hline & & \begin{tabular}{|l|} 
Green \\
Façade \\
\end{tabular} & \begin{tabular}{|r|}
$\begin{array}{r}\text { Green } \\
\text { Roof }\end{array}$ \\
\end{tabular} & Vegetation & \begin{tabular}{|c|}
$\begin{array}{c}\text { Spring } \\
\text { Summer }\end{array}$ \\
\end{tabular} & \begin{tabular}{|r|} 
Autumn \\
Winter
\end{tabular} & & \\
\hline $\begin{array}{c}\text { Thessaloniki } \\
\text { Greece }\end{array}$ & $\begin{array}{c}\text { Temperature } \\
\text { Mediterranean }\end{array}$ & $\sqrt{ }$ & & & $\sqrt{ }$ & & 3 days, measurements every 4 hours & $\begin{array}{l}\text { Chatzidimitriou,Yannas, } \\
2004\end{array}$ \\
\hline Singapore & Tropical & $\sqrt{ }$ & & & $\sqrt{ }$ & $\sqrt{ }$ & $\begin{array}{c}3 \text { clear days, distances : } 0.15 \mathrm{~m} / \\
0.30 \mathrm{~m} / 0.60 \mathrm{~m} / 1.00 \mathrm{~m}\end{array}$ & Wong et al. , 2010 \\
\hline $\begin{array}{l}\text { Golmés } \\
\text { Spain }\end{array}$ & $\begin{array}{c}\text { Continental } \\
\text { Mediterranean }\end{array}$ & $\sqrt{ }$ & & & $\sqrt{ }$ & & $\begin{array}{l}\text { Weekly at 2:00 pm at different solar } \\
\text { orientation points }\end{array}$ & $\begin{array}{l}\text { Pérezet al ., } 2011 \text { \& } \\
\text { Dimoudi, Nikolopoulou, } \\
2003\end{array}$ \\
\hline $\begin{array}{l}\text { Nagoya } \\
\text { Japan }\end{array}$ & $\begin{array}{l}\text { Humid } \\
\text { Subtropical }\end{array}$ & & & $\sqrt{ }$ & $\sqrt{ }$ & $\sqrt{ }$ & 4 days, $11: 00 \mathrm{am}$ and $10: 00 \mathrm{pm}$ & Onishi et al., 2010 \\
\hline $\begin{array}{l}\text { Madrid } \\
\text { Spain }\end{array}$ & $\begin{array}{c}\text { Continental } \\
\text { Mediterranean }\end{array}$ & & & $\sqrt{ }$ & $\sqrt{ }$ & $\sqrt{ }$ & $\begin{array}{c}3 \text { days, } 9: 00 \mathrm{am}, 12: 00 \mathrm{am}, 3: 00 \mathrm{pm}, \\
6: 00 \mathrm{pm} \text { and 9:00 pm }\end{array}$ & Tumini, 2012 \\
\hline Taiwan & Subtropical & & $\sqrt{ }$ & & & $\sqrt{ }$ & $\begin{array}{l}\text { Period between 10:00 am and 10:00 } \\
\text { pm }\end{array}$ & Liang, Huang, 2011 \\
\hline $\begin{array}{l}\text { Tel Aviv } \\
\text { Israel }\end{array}$ & Mediterranean & & & $\sqrt{ }$ & $\sqrt{ }$ & & $\begin{array}{c}2 \text { days, } 6: 00 \mathrm{am}, 9: 00 \mathrm{am}, 3: 00 \mathrm{pm} \\
6: 00 \mathrm{pm} \text { and } 00: 00 \mathrm{am}\end{array}$ & $\begin{array}{l}\text { Shashua-Bar, Hoffman, } \\
2004\end{array}$ \\
\hline $\begin{array}{l}\text { Rome } \\
\text { Italy }\end{array}$ & Mediterranean & & & $\sqrt{ }$ & $\sqrt{ }$ & $\sqrt{ }$ & $\begin{array}{c}2 \text { days, 10:00 am, } 2: 00 \mathrm{pm} \text { and 6:00 } \\
\mathrm{pm}\end{array}$ & $\begin{array}{l}\text { Salata } \text { et al., } 2015 \text { \& } \\
\text { Santamouris, } 2013\end{array}$ \\
\hline
\end{tabular}

Fig. 4. Summary of experimental investigations carried out in different countries.

$[6,9,16,24,26]$, the second measurement period occurred in the autumn period.

In terms of equipment, the air temperature was measured using the digital thermometer Fluke 52II with two channels T-type thermocouples ( $\pm 0.5^{\circ} \mathrm{C}$ accuracy). The wind speed was measured using digital Testo equipment, anemometer model 350XL-testo454 ( $\pm 0.2 \mathrm{~m} / \mathrm{s}$ accuracy). The relative humidity was measured using a digital metre Laser model GP3181B ( $\pm 5 \%$ accuracy). Solar radiation measurements were performed using the pyranometer Ingenieurbüro-Solar irradiation sensor Si-02-K $\left( \pm 0.5{ }^{\circ} \mathrm{C}\right.$ accuracy).

Care was taken regarding the use and handling of equipment during data collection so as not to affect the measurement of records. For example, for the data recorded manually, a $30 \mathrm{~s}$ time of stabilizing the equipment to collect the measured data was defined. The temperature and humidity measurements were performed at the height of $1.5 \mathrm{~m}$ and the wind speed at $1.7 \mathrm{~m}$, aiming to record the data measurements protected from direct sunlight and at general heights for human beings while in urban space. The radiation measurements were performed at a height of $1.5 \mathrm{~m}$ with the device pointing at the vertical and horizontal positions.

Taking into account that the two walls could not be measured simultaneously and there was a change of temperature throughout the day, both measurements were related to the referential common temperature of Madrid Alameda weather station at the exact time of measuring. This process enabled us to strictly relate the measured temperatures to one another.

Radiation was monitored on average $30 \mathrm{~min}$ before and $30 \mathrm{~min}$ after (intercalated with measurements of other variables), in the same three periods of the day (morning, afternoon and evening). The solar radiation measurement point was fixed at point 1 of Wall $1(0.5 \mathrm{~m})$ due to the influence of direct radiation on the facade and also the reflection of the horizontal radiation of the pavement.

\section{Results and discussion}

The data collected daily in situ in the two campaigns comprise 3 measurements on each of the 8 points, a total of 24 daily measurements and in the total campaign, 144 measurements of climatic air temperature parameters, humidity and air velocity. Two weather stations: Chamberi (Lat.40 $26^{\prime} 15.86^{\prime \prime} \mathrm{N} /$ Long.3${ }^{\circ} 41^{\prime} 59.11^{\prime \prime} \mathrm{W}$ ) and Alameda (Lat. $40^{\circ} 24^{\prime} 41.35^{\prime \prime} \mathrm{N} /$ Long. $3^{\circ} 41^{\prime} 37.70^{\prime \prime} \mathrm{W}$ ) were selected in the vicinity of the case study area in order to obtain actual recorded values of air temperature, humidity, velocity and wind direction during the two phases and their respective periods of measurement campaigns. For this study, only data from the Alameda station were submitted due to the proximity of Wall 1 . The Alameda station is located approximately $150 \mathrm{~m}$ away from the object of study. Data collected were related to air temperature and humidity [27]. The wind velocity data collected at the Chamberi station, as well as the values obtained in situ showed that throughout all the campaign days, the wind velocity had a low influence and was characterized according to the International classification as a "gentle breeze" or point 2 of the Beaufort Scale. For this reason and considering that both walls are located in a confined city centre square, this parameter was disregarded in the calculations.

\subsection{Thermal behaviour during the summer}

Meteorological conditions measured by the Alameda weather station between the 23rd and the 25th of September were considered as a reference for the behaviour of temperature and humidity in the microclimate analysis (Fig. 5). The thermal behaviour found served as a comparative analysis between Walls 1 and 2 on the same days and times.

It can be observed that on day 1 (23rd of September 2015), minor variations in the air temperature and humidity were observed throughout the day due to the cloudy weather conditions over the period analysed. Furthermore, on day 3 (25th of September 2015) the measurements revealed higher temperatures and lower moisture values. Throughout the day, we obtained temperatures progressively ascending and humidity descending profiles. Humidity was between 20 and $30 \%$ as observed at the periods 1:00 p.m. and 6:00 p.m.

In situ temperature measurements of the wall 1 and the wall 2 confirmed (Fig. 6) that the temperature range between measurements from point 1 to point 4 presented a good thermal reduction behaviour throughout day 1 between the first and third measurements. On day 2, 24th of September 2015 even with direct incidence of sun on wall 1 , there was no significant variation in temperature values throughout the day.

\subsection{Thermal behaviour during autumn}

The measurements of Alameda weather station on November 16,17 and 19 (Fig. 7) show that there is temperature rise throughout the day. In the morning, at 9:00 a.m., temperature was between $8.3^{\circ} \mathrm{C}$ and $10.3^{\circ} \mathrm{C}$ and in the evening period, around 4:00 p.m., the highest temperatures occurred, between $16.7{ }^{\circ} \mathrm{C}$ and $20.3{ }^{\circ} \mathrm{C}$. Moisture had a similar behaviour for the three days, of $85 \%$ in the 


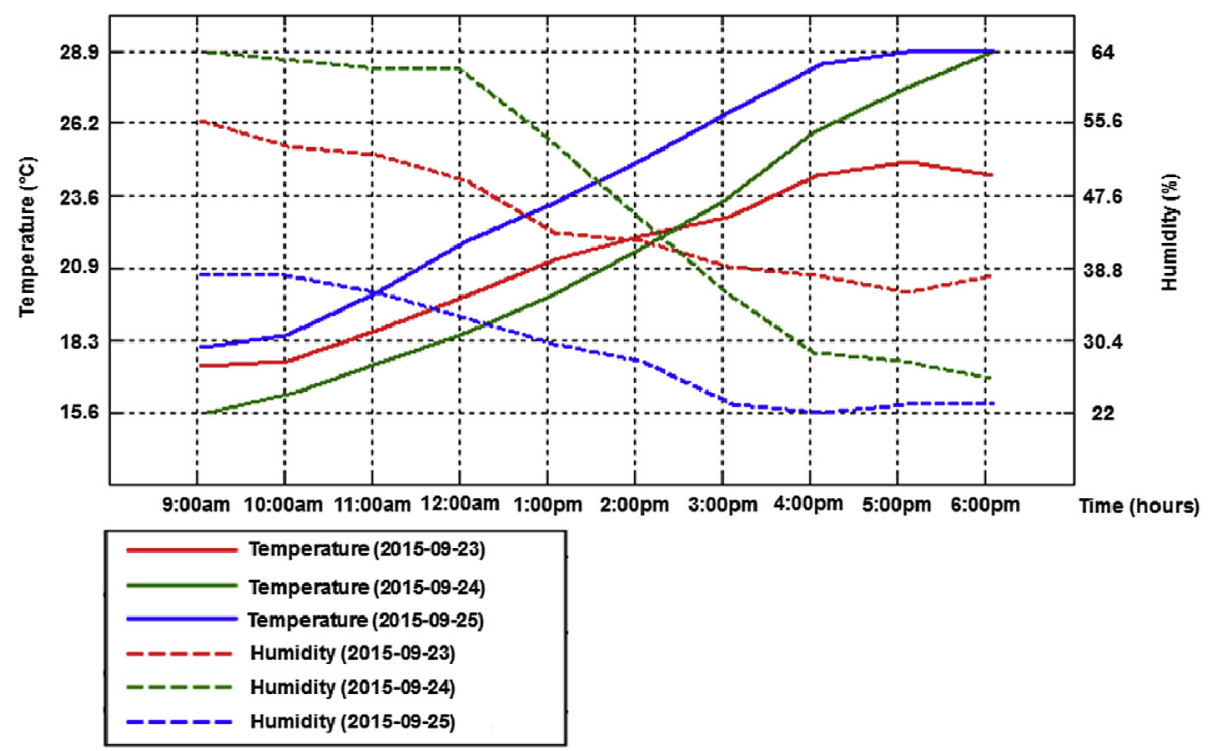

Fig. 5. Measured meteorological conditions in Alameda station on September 23, 24 and 25, 2015.

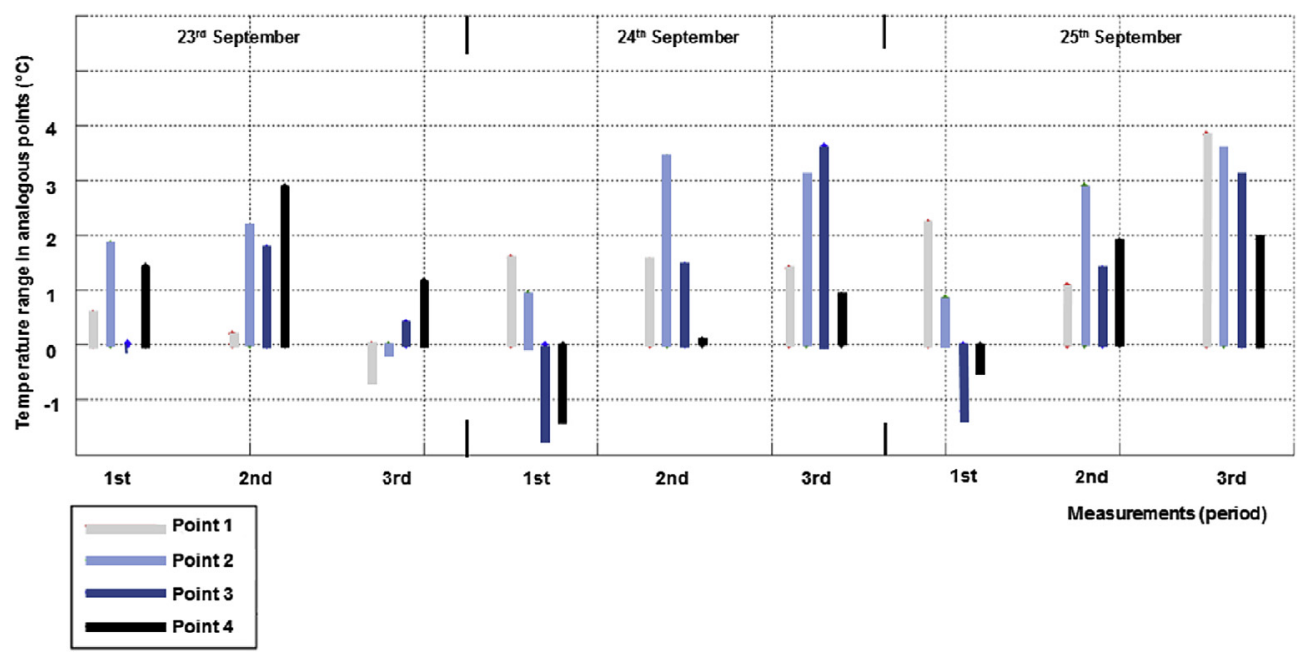

Fig. 6. First campaign - Temperature range between analogous points.

morning at 9:00 a.m., decreasing throughout the day. There was a single exception of one day, on November 17, when the relative humidity did not show this behaviour, significantly increasing for the period between midday and 3:00 p.m. (to a maximum of 100\%) and, starting to decrease afterwards.

The thermal variation of in situ temperature measurements between Walls 1 and 2 is shown in Fig. 8. In both walls, the reference was adopted by the Alameda station, as explained before, because the measurements were taken at different times, therefore requiring a common framework to be equalized.

The range of temperature variations between measurements from Point 1 to Point 4 showed a similar behaviour in the first measurements carried out on November 16 and 19, 2015 as the highest $1{ }^{\circ} \mathrm{C}$ temperature range was between Points 1 and 4 . For the second and third measurements, there was a similar behaviour on November 16 and 19, 2015 when the range reached a peak thermal variation of $1.2^{\circ} \mathrm{C}$.

\subsection{Solar radiation}

In the second campaign, a measurement of the solar radiation was performed in situ to complement the microclimate analysis in the thermal behaviour study.

The reason of this radiation measurement is that the Wall 1 was exposed to direct and diffuse solar and the reflected solar from the ground near it and, the Wall 2 , since it was shadowed, received only the diffuse solar radiation. So, in order to enable a better comparison of the results, in the second campaign the solar radiation was measured in the nearest point to the wall exposed to direct sunlight (considered point 1 of Wall 1). To perform this measurement, the equipment was used in two different positions, vertical and horizontal. The horizontal position was responsible to the measurement of the direct sunlight radiation, but since the incidence is not perpendicular to the equipment, it was necessary to compose this incidence with the horizontal measurement. The horizontal measurement was also responsible to know the diffuse reflected 


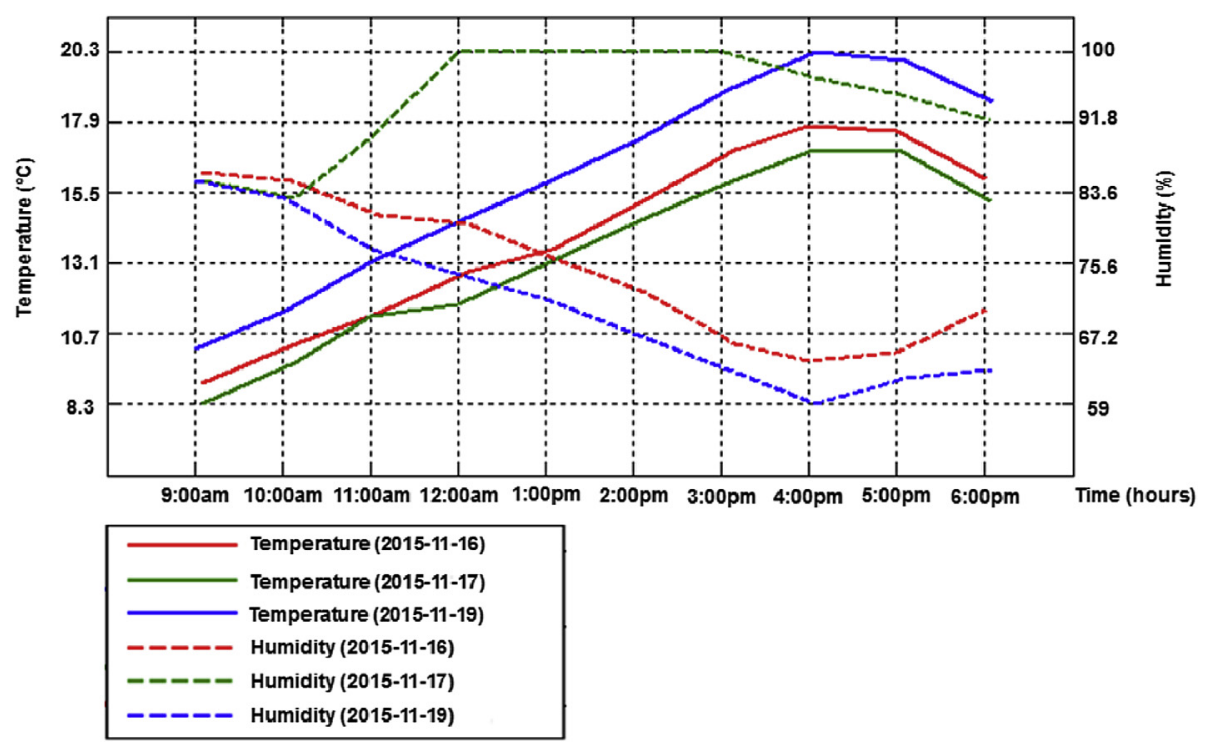

Fig. 7. Measured meteorological conditions in Alameda station on November 16, 17 and 19, 2015.

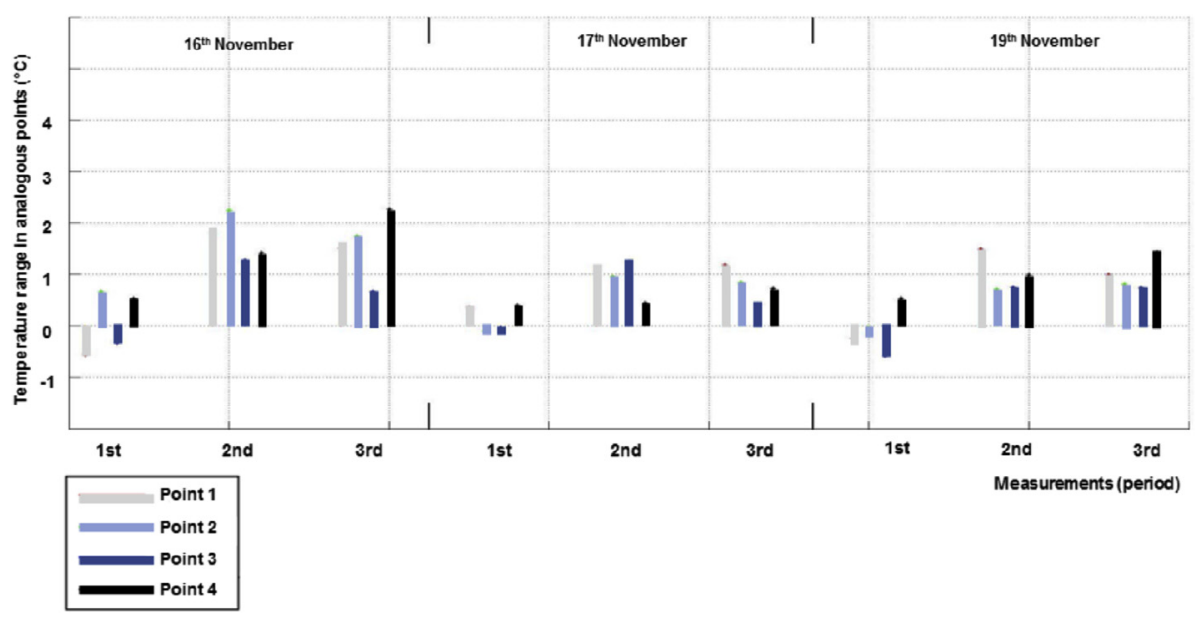

Fig. 8. Second campaign - Temperature range between analogous points.

radiation of the ground. In order to define the solar incidence area of Wall 2 in view of its homogeneity, a small area was adopted as being representative of the whole. Furthermore, in order to ensure that the transmittancy $(\tau)$ is zero, a sufficient thickness was adopted to calculate a representative volume so that Wall 2 can be considered as opaque.

Therefore, for the calculation of the representative area (A), formula 1 is used:

$A=l . h$

where:

1 - length of the section; and

$h$ - height of the section.

To estimate the representative volume $(\boldsymbol{V})$ of the area $(\boldsymbol{A})$, Equation (2) is used:

$\boldsymbol{V}=\boldsymbol{A} \cdot \boldsymbol{d}$ where:

$\boldsymbol{A}$-area of the section; and $d$-thickness of the section.

In order to obtain the mass $(m)$ of the Wall 2 sample, Equation (3) is used:

$\boldsymbol{m}=\boldsymbol{\rho} . \boldsymbol{V}$

where:

$\boldsymbol{\rho}$ - density of the wall material; and

$\boldsymbol{V}$ - volume of the section.

Considering a sample of $1 \mathrm{~m}^{3}$ wall with granite density of $2800,0 \mathrm{~kg} / \mathrm{m}^{3}$, the equivalent mass of a Wall 2 sample is $2800 \mathrm{Kg}$.

In order to obtain the absorptance, derived from Moran [28], p. 483, Equation (4) is used: 
$\sigma+\alpha+\tau=1$

where:

$$
\begin{aligned}
& \alpha-\text { reflectance; } \\
& \sigma-\text { absorptance; and } \\
& \tau-\text { transmitancy. }
\end{aligned}
$$

Considering that Wall 2 is opaque, as stated before, Equation (4) can be simplified into Equation (5), taken from the same author:

$\sigma+\alpha=1$

Therefore, assuming a reflectance of 0.29 for granite, an absorptance of 0.71 is obtained [29]. In order to calculate the temperature increase at each point for Wall 2, the fundamental law of calorimetry was used (Eq. (7)), considering the added heat (Q) as accumulated from the early hours of the day until the time of the in situ measurement or from Equation (6), the solar incidence at the sunrise as zero, the temperature collected from station Alameda, and the composed measurement of the horizontal and vertical radiation employed as explained above (direct incidence of sunlight and reflected from the ground):

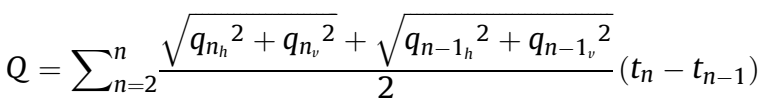

where:

$n$ - measurement at the actual time of the in situ measurement;

$n-1-$ point at the time before;

$q_{n_{h}}$ - horizontal solar radiance measurement for point " $\mathrm{n}$ ";

$q_{n_{v}}$ - vertical solar radiance measurement for point " $\mathrm{n}$ "; and

$t_{n}-$ time at point " $n$ " measurement.

$Q=$ m.c. $\left(T_{f}-T_{i}\right)$

where:

$Q$ - added heat (kJ);

$c$ - specific heat $\left(\mathrm{kJ} / \mathrm{kg}^{\circ} \mathrm{C}\right)$;

$m$ - mass of the sample $(\mathrm{kg})$;
$T_{i}$ - initial temperature $\left({ }^{\circ} \mathrm{C}\right)$; and

$T_{f}$ - final temperature $\left({ }^{\circ} \mathrm{C}\right)$.

Assuming the final temperature as the temperature gradient and the initial temperature as null, Equation (7) can be rewritten in Equation (8):

$T_{f}=\frac{Q}{m \cdot c}$

Fig. 9 shows the temperature values converted at point 1 of Wall 2 , considering the same incidence of solar radiation as in Wall 1 . The difference between the measured temperature and the converted temperature at point 1 in the morning showed an average increase of $0.2^{\circ} \mathrm{C}$. However, the temperature rise was significant in the later period ranging from $1.2{ }^{\circ} \mathrm{C}$ to $2.4{ }^{\circ} \mathrm{C}$.

\section{Conclusion}

A comparative analysis of the experimental results obtained from a green wall and a bare wall, both located in the same micro climate in the city centre of Madrid, demonstrates that green façades can have a potential significant temperature reduction in the surrounding microclimate. We found values and results that are in line with similar studies developed in some countries such as Germany, Spain, Greece, Singapore in which the values of temperature reduction in the presence of vegetation were between $2{ }^{\circ} \mathrm{C}$ and $5{ }^{\circ} \mathrm{C}[8,9,16$ and20]. In the current case study, the maximum temperature reduction according to in situ measurements was $2.7^{\circ} \mathrm{C}$ for the Caixa Fórum Museum green wall.

This value was obtained over two consecutive days during the first campaign held in the summer. This season when the air temperature is higher and the humidity is lower, representing drier days, the results showed a greater potential of the reduction in the air temperature in the microclimate surrounding the green façade. During the second campaign held during the autumn, temperatures were lower and humidity data of the air higher, with significantly wetter days. Note that the temperature reduction at the different measured distances was smaller and was less representative when compared to the summer season. A maximum temperature reduction of $1.5^{\circ} \mathrm{C}$ was found between Point 1 and Point 4 $(4.5 \mathrm{~m})$ on the green wall. If this value is converted according to the calculation of similar conditions of sunlight in both façades, this

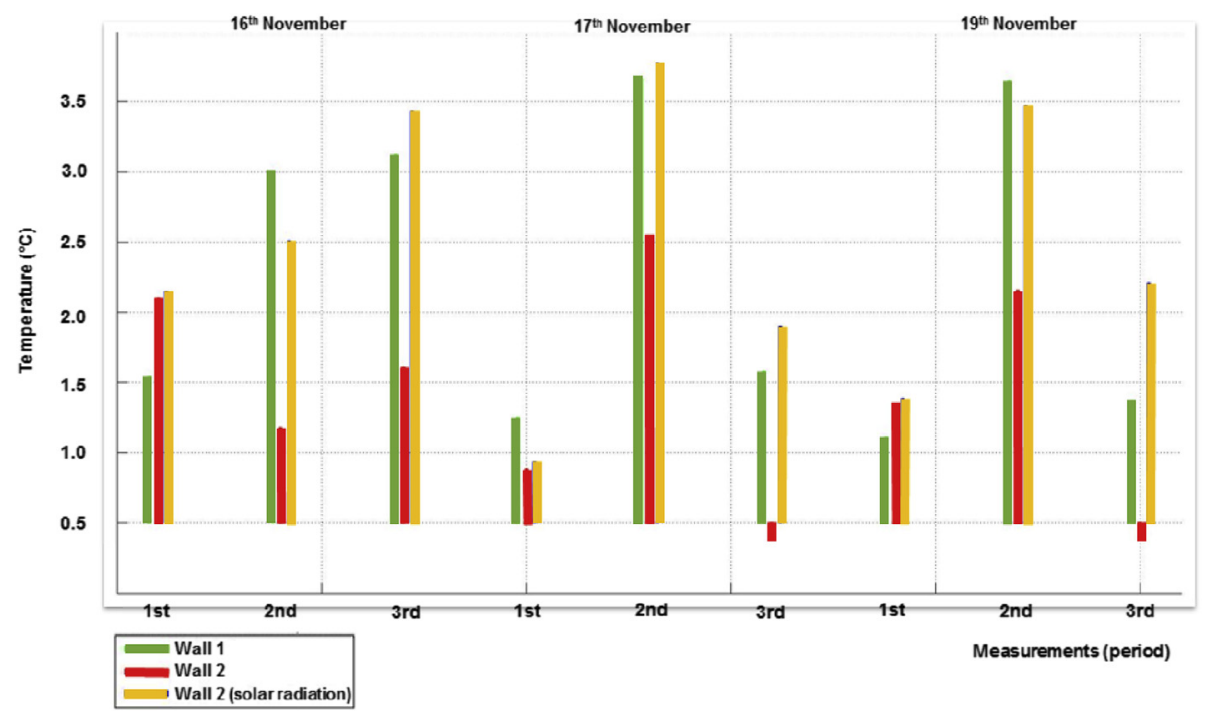

Fig. 9. Second campaign - Temperature variations (between Points 1-4) in Walls 1 and 2. 
reduction reaches $2.3{ }^{\circ} \mathrm{C}$. Therefore, there is a significant temperature reduction in the intermediate micro climate environment of the green wall, even in the autumn.

Field data collection in the actual urban space can cause more problems than using simulation scenarios, but it adds a realistic dimension of the conditions of the urban environment. This especially applies to singular elements such as the green wall of the Caixa Fórum Museum. Moreover, as proven in this case study, careful planning of the experimental work and monitoring the results can help to minimize the constraints of in-situ measurements such as location and access to equipment in terms of space and time, as well as similar solar exposition for the sample walls. The complementary solar radiation parameter, accounting for the real influence of the solar orientation in the studied walls, achieved the purpose of allowing in situ feasible measurement campaigns and, consequently, enriched the discussion of the results.

The obtained results apply to the characteristics of the studied façade (Wall 1). It should be mentioned that this is an atypical façade because it does not have windows and other openings. Research carried out in conventional dwellings with typical façades is likely to lead to different results.

In order to guide future work, further clarification is needed regarding sources of thermal uncertainty in the urban environment and various other influences exerted on the outdoor thermal behaviour, such as urban morphology, density of green areas and shade.

\section{Acknowledgements}

The authors are grateful to the European Union Erasmus+ Program for funding the Portuguese researchers' trips and visits to Madrid.

\section{References}

[1] J.G. Cortesão, F.B. Alves, H. Corvacho, M. Rhodes, The climatic skin of urban spaces, Int. J. Hous. Sci. its Appl. 33 (2009) 105-115.

[2] El País. http://ccaa.elpais.com/ccaa/2016/01/23/madrid/1453573500 585056 html, 2016 (Acessed on 22 February 2016).

[3] P. Bosselmann, E. Arens, K. Dunker, R. Wright, Urban form and climate: case study, Toronto, J. Am. Plan. Assoc. 61 (1995) 226-239.

[4] G. Pérez, L. Rincón, A. Vila, J.M. González, L.F. Cabeza, Green vertical systems for buildings as passive systems for energy savings, Appl. energy 88 (2011) 4854-4859.

[5] A. Dimoudi, M. Nikolopoulou, Vegetation in the urban environment: microclimatic analysis and benefits, Energy Build. 35 (2003) 69-76.

[6] K. Perini, M. Ottelé, A.L.A. Fraaij, E.M. Haas, R. Raiteri, Vertical greening systems and the effect on air flow and temperature on the building envelope, Build. Environ. 46 (2011) 2287-2294.

[7] K. Perini, et al., Vertical greening systems, a process tree for green façades and living walls, Urban Ecosyst. 16 (2013) 265-277.

[8] F. Bartfelder, M. Köhler, Experimentelle unter-suchungen zur function von fassadenbegrünungen, Dissertation, 1987. TU Berlin 612S.

[9] A. Onishi, X. Cao, T. Ito, F. Shi, H. Imura, Evaluating the potential for urban heat-island mitigation by greening parking lots, Urban For. Urban Green. 9 (2010) 323-332.

[10] E. Eumorfopoulou, K. Kontoleon, Experimental approach to the contribution of plant-covered walls to the thermal behavior of building envelopes, Build. Environ. 44 (2009) 1024-1038.

[11] K. Kontoleon, E.A. Eumorfopoulou, The effect of the orientation and proportion of a plant-covered wall layer on the thermal performance of a building zone, Build. Environ. 45 (2010) 1287-1303.

[12] H.H. Liang, K.T. Huang, Study on rooftop outdoor thermal environment and slab insulation performance of grass planted roof, Int. J. Phys. Sci. 6 (2011) 65-73.

[13] A. Scherba, D.J. Sailor, T.N. Rosenstiel, C.C. Wamser, Modeling impacts of roof reflectivity, integrated photovoltaic panels and green roof systems on sensible heat flux into the urban environment, Build. Environ. 46 (2011) 2542-2551.

[14] A.L. Pisello, M. Santamouris, F. Cotana, Active cool roof effect: impact of cool roofs on cooling system efficiency, Adv. Build, energy Res. 7 (2013) 209-221.

[15] F. Salata, I. Golasi, A.L. Vollaro, R.L. Vollaro, How high albedo and traditional buildings' materials and vegetation affect the quality of urban microclimate. A case study, Energy Build. 99 (2015) 32-49.

[16] N. Wong, et al., Thermal evaluation of vertical greenery systems for building walls, Build. Environ. 45 (2010) 663-672.

[17] E. Alexandri, P. Jones, Temperature decreases in an urban canyon due to green walls and green roofs in diverse climates, Build. Environ. 43 (2008) 480-493.

[18] A. Synnefa, A. Dandou, M. Santamouris, M. Tombrou, N. Soulakellis, On the use of cool materials as a heat island mitigation strategy, J. Appl. Meteorol. Climatol. 47 (2008) 2846-2856.

[19] T. Susca, S.R. Gaffin, G.R. Dell'Osso, Positive effects of vegetation: urban heat island and green roofs, Environ. Pollut. 159 (2011) 2119-2126.

[20] K.R. Smith, P.J. Roebber, Green roof mitigation potential for a proxy future climate scenario in Chicago, Illinois, J. Appl. Meteorol. Climatol. 50 (2011) 507-522.

[21] Comunidad de Madrid, Diagnóstico Ambiental, Consejería de Medio Ambiente y Ordenación del Territorio, Secretaria General Técnica, Área de Información y Documentación Ambiental, Madrid, 2014. http://www.madrid.org/cs (accessed 03 December 2015).

[22] A. Chatzidimitriou, S. Yannas, Microclimatic studies of urban open spaces in Northern Greece, in: Proc. PLEA, 2004, pp. 83-88.

[23] L. Shashua-Bar, M.E. Hoffman, Quantitative evaluation of passive cooling of the UCL microclimate in hot regions in summer, case study: urban streets and courtyards with trees, Build. Environ. 39 (2004) 1087-1099.

[24] I. Tumini, El microclima urbano en los espacios abiertos: estudio de casos en Madrid, Doctoral dissertation, Arquitectura, 2013.

[25] S.S. Castro, Doctoral dissertation, Evaluación teórica y experimental de una torre de viento evaporativa para acondicionamiento térmico de espacios abiertos, vol. 2012, Universidad Politécnica de Madrid, 2012.

[26] H. Feng, K. Hewage, Energy saving performance of green vegetation on LEED certified buildings, Energy Build. 75 (2014) 281-289.

[27] Weather Underground. http://www.http://www.wunderground.com, 2016 (accessed on 24 August 2015).

[28] M.J. Moran, H.N. Shapiro, B.R. Munson, D.P. DeWitt, Introduction to thermal systems engineering: thermodynamics, Fluid Mechanics and Heat Transfer, John Wiley \& Sons, New York, 2003

[29] N.L. Alchapar, E.N. Correa, M.A. Cantón, Índice de reflectancia solar de revestimientos verticales: potential para la mitigación de la isla de calor urbana, Ambiente Construído 12 (2012) 107-123. 